\title{
ПРОФЕССИОНАЛЬНЫЕ ЖУРНАЛИСТСКИЕ ДИСЦИПЛИНЫ В СИСТЕМЕ СОВРЕМЕННОГО УНИВЕРСИТЕТСКОГО ОБРАЗОВАНИЯ
}

\author{
О. Е. Коханая \\ (Московский гуманитарный университет)
}

Аннотация: В статье излагается опыт работы кафедры журналистики Московского гуманитарного университета по подготовке журналистов; рассматриваются особенности учебных дисциплин.

Подготовлено на основе доклада на ХІІ Международной научной конференции «Высшее образование для ХХІ века» (3-5 декабря 2015 г.) в Московском гуманитарном университете.

Ключевые слова: журналист; подготовка журналистов; Московский гуманитарный университет; российские СМИ; студенты-журналисты; медиаобразование

\section{CORE COURSES FOR JOURNALISM MAJORS IN THE SYSTEM OF CONTEMPORARY UNIVERSITY EDUCATION}

\author{
O. E. Kokhanaya \\ (Moscow University for the Humanities)
}

\begin{abstract}
The article reflects on the experience of the Department of Journalism at Moscow University for the Humanities in training journalists, with a special focus on the academic disciplines the curriculum provides for journalism majors. The article is based on the paper given at the 12th International research conference "Higher education for the 21st century" (December 3-5, 2015) at Moscow University for the Humanities.

Keywords: journalist; education in journalism; Moscow University for the Humanities; mass media in Russia; journalism majors; education in mass media

Систему российского образования лихорадит от обилия инициатив и перманентно изменяющихся условий функционирования: введение ЕГЭ, вхождение в Болонский процесс, череда новых образовательных стандартов, выявление неэффективных вузов, определение непрофильных специальностей и т. д. Одним из результатов кризиса образования является
\end{abstract}


распространение функциональной неграмотности, которое стало повсеместным. Ее причинами И. Н. Блохин называет: репродуктивное, нетворческое, строго алгоритмизированное мышление (ЕГЭ); недостаточная операбельность знаний и умений; низкий уровень общей культуры и нравственной надежности личности; пассивная стратегия поведения личности в мире массовой информации (Блохин, 2013: 18).

На сегодняшний день первые творческие работы студентов-первокурсников, вчерашних школьников, поступивших на направление «Журналистика» в Московский гуманитарный университет, можно условно поделить на три категории. Тексты тех, кто прилежно учился в школе, отличаются реферативной формой написания работ, как правило, сухим, наукообразным языком со слабыми, но неизменными попытками рефлексии и обобщений (первая группа). Вторую группу представляют те студенты, кто не усвоил директивы учителей по подготовке реферативных текстов, практически не обладает элементарной логикой, крайне скуден словарный запас, часты повторы слов и словосочетаний; по заданной теме они способны написать три-шесть предложений. Третью, крайне малочисленную группу составляют первокурсники с признаками одаренности. Они интуитивно раскрывают тему эмоционально, сюжетно, выстраивают некую композицию текста. Подчас их творческие изыскания настолько не похожи на сочинения сокурсников, подчас неожиданны для них самих, что они сами не знают, что делать со своей одаренностью. Да и узнают о своих способностях подчас впервые от преподавателей кафедры журналистики. Последняя группа крайне малочисленна, но на нее мы возлагаем самые большие надежды.

Независимо от «попадания» студентов в ту или иную условно выделенную нами категорию, работы двух третей студентов с точки зрения грамотности невозможно оценить на положительную оценку, также, очевидно, что тексты практически всех первокурсников необходимо прорабатывать и с точки зрения формальной логики, с точки зрения воздействия их на аудиторию.

Сжатая, компрессионная подготовка бакалавров ориентирована, в основном, на практические дисциплины. «Современные тенденции в системе образования связаны прежде всего с переходом от интеллектуального обучения к интегральному. Если в основе интеллектуального обучения - передача знаний по конкретной дисциплине, то интегральное обучение рассматривает мир как целостную систему, поэтому его методики подчеркнуто ориентированы на изучение не отдельных тем, а на более широкий когнитивный контекст, позволяющий разглядеть связи между разными дисциплинами, явлениями, процессами» (Сметанина, 2015: 301-302). Главная цель профессионального образования, которое 
является сложным, многокомпонентным процессом, - это подготовка профессионально грамотных и мировоззренчески полноценных специалистов, владеющих навыками написания текстов, современными методами и технологиями для работы в основных коммуникационных отраслях масс-медиа: журналистике, связях с общественностью, рекламе (Летуновский, 2013: 20).

Очевидно, что все усилия обучающих с первых дней должны быть направлены на развитие творческой составляющей личности студента. Если мы обучаем актера или режиссера, львиная доля учебного времени отводится занятиям под общим названием «Режиссура и (или) мастерство актера». Если мы обучаем литераторов, писателей, также их творческий поиск осуществляется на занятиях под общим названием «Творческий семинар». Весь учебный процесс имеет одну системную цель: образование и преобразование личности обучаемого в профессионала (актера, режиссера, литератора). На сегодняшний день, в условиях обучения журналиста, причем универсального (конвергентного) журналиста, иначе он вряд ли трудоустроится по специальности после окончания вуза, - в сжатые сроки обучения по программе бакалавра (4 года - дневная форма обучения), мы также должны поставить перед собой системную цель: все дисциплины, традиционно составляющие так называемый «профессиональный блок», должны осуществлять подготовку журналиста-практика, то есть быть практикоориентированными. Усиление роли практического аспекта преподавания в бакалавриате связано не только с сокращением времени обучения, но и с прагматической ориентированностью студентов нацеленных на работу в профессии (Бережная, 2014: 55).

Выход из состояния тактической неопределенности состоит в изменении базовой модели журналистского профессионального образования.

«С первого курса приучать студентов работать, писать. Уверен, большинство из них к четвертому курсу, хотя и считают себя корифеями, еще «не расписались», не чувствуют стиля, не могут выделить главное в материале, не умеют выстроить систему аргументации, писать убедительно. На все это надо время. Вот почему писать надо каждую неделю, а не к зачету или сессии. Это учебник можно прочесть за ночь, а выработать навык - нельзя. И потому весь первый год нужен еженедельный тренаж, и практика в печатных СМИ летом - как итоговая.

Такой подход, вероятно, потребует коррекции учебных планов. Значит, надо их изменить, потому что многое изменилось у работодателей, в самих редакциях, на рынке труда», - справедливо выдвигает предложение преподаватель Санкт-Петербургского государственного университета С. В. Грачев (Грачев, 2013: 34).

С первых дней обучения подготовку бакалавров необходимо совме- 
стить с редакционным производством, когда профессиональная подготовка идет параллельно с профессиональным журналистским трудом (Блохин, 2013: 17). Не раз от преподавателей факультетов журналистики мы узнавали поразительную статистику: не более 15-20\% выпускников «пишущие». Что тут говорить о трудоустройстве по профессии!

Кафедра журналистики МосГУ решает этот вопрос так: учебные занятия в редакции «Литературной газеты» с одним из руководителей редакционного коллектива (Л. В. Колпаковым, заместителем главного редактора); в рамках учебного процесса в стенах университета деятельность общественной студенческой редакции учебной газеты «Проба пера». Причем, работа в газете является частью учебно-ознакомительной (двухнедельной по учебному плану бакалавров) практики, которая реструктурирована и фактически начинается с первых же дней учебы в университете. Открытая защита практики осуществляется в рамках студенческой научно-практической конференции, что способствует формированию будущих профессиональных интересов, развитию коммуникативных навыков, позволяет студентам-журналистам познакомиться с технологией проведения PR-мероприятий (Смеюха, 2015: 164).

Отношения, в которые студенты как авторы публикаций вступают между собой и редактором газеты (как правило, это преподаватель кафедры, реализующий курс «Выпуск учебных СМИ»), достаточно точно моделируют те взаимосвязи, которые возникают у выпускника университета, приходящего на работу в редакцию, а ранее - у студента, приходящего в редакцию на практику (Головин, Коханая, 2015: 366).

Используя метод моделирования и проектную методику, мы создаем такую учебно-воспитательную среду, когда учебно-практическая деятельность направлена на моделирование различных форм и видов журналистской деятельности. «В этом случае удается достигнуть максимального эффекта в воздействии на широкий спектр личностных параметров обучаемого, тем самым решая вопросы освоения будущей профессии не только на уровне методов работы, технологий, но и овладения профессиональной культурой, понимания мотивационных, а главное психологических алгоритмов функционирования журналиста в системе малых профессиональных групп, часто составляющих основу творческого процесса», - отмечает исследователь метода моделирования в журналистском образовании В. П. Летуновский (Летуновский, 2013: 22).

Этот принцип профессионального моделирования в более сложной форме представлен в деятельности учебного телерадиокомплекса, на базе которого осуществляется основная часть профильных дисциплин учебного плана студентов, выбравших профиль подготовки «Телерадиожурналистика». В рамках бакалавриата необходимые профессиональные компетенции студент должен освоить в двухгодичный срок (на 3-4 кур- 
сах), то есть учебный процесс должен быть крайне интенсивным. Зато журналисты, знакомые с особенностями изготовления медийного продукта, как правило, уже имеют представления о возможностях медийного производства, им несложно определить степень качества предлагаемой продукции, что отмечает в своих работах известный исследователь в области медиалогии В. В. Смеюха (Смеюха, 2015: 164).

Хочется обратить внимание на то, что основная часть общепрофессиональных компетенций вырабатывается непосредственно в учебных аудиториях, в процессе реализации учебного плана (Кощиенко, 2014: 8). И здесь крайне важен в создании журналистского продукта в рамках учебного процесса междисциплинарный подход, на котором в общем-то всегда основывались методики обучения в высшей школе профессиональным журналистским предметам. На первом курсе авторами учебной газеты становятся студенты, подчас не имеющие умений и навыков написания не только журналистского, но и просто собственного творческого текста, элементарного школьного сочинения. Представляется логичным, что преподаватели профессиональных базовых дисциплин «Логика», «Современный русский язык» могли бы на практических (семинарских) занятиях в рамках учебного процесса прорабатывать подчас первые журналистские работы студентов с точки зрения логики, стилистики, элементарной грамотности. Лучшие работы, с точки зрения педагогов этих дисциплин, рекомендовать к опубликованию. Актуальные темы практических заданий может подсказать главный редактор газеты, преподаватель кафедры журналистики.

Не секрет, что за годы работы по подготовке журналистов я не раз слышала от студентов вопрос: «Зачем нам “Логика”, какое она имеет отношение к журналистике? Мы ничего не понимаем в ней!» Но ни один преподаватель «Логики» ни разу не поинтересовался, чего же ожидает от него кафедра, в чем практическая необходимость его дисциплины (у журналистов это всего один семестр на первом курсе), как она встроена в общий процесс по освоению студентами соответствующих компетенций. Дисциплина «Современный русский язык», входящая в языковой модуль наряду со «Стилистикой и литературным редактированием» и предваряющая ее, также необходима для доработки материалов для студенческой газеты.

От процесса освоения студентами дисциплин языкового модуля кафедра ожидает помощь в редактировании публикаций в студенческой газете, в освоении студентами новых медиа-жанров, таких, например, как пресс-релиз на заданную тему. Ведь в рамках ежегодного Международного фестиваля студенческой рекламы, который проводит факультет рекламы Московского гуманитарного университета, в одной из номинаций, касающейся медиа-текста, естественно, должны принять участие студенты-журналисты (Бородай, 2008). Это крайне важно при подготов- 
ке специалиста в области масс-медиа в широком смысле слова, у которого есть наибольшее количество шансов при будущем трудоустройстве (Ильинский, 2006). Тем более в нынешней непростой экономической ситуации, когда организации медиа-рынка уже претерпели сокращения штатов, и теперь на одного специалиста подчас возлагаются весьма разнородные должностные обязанности. А переписывать и перепроверять материал за новичка просто некому - не раз слышали мы от действующих журналистов при устройстве наших студентов в редакции, на базы практики. То есть необходима всесторонняя работа над конкретным ученическим текстом в рамках профессиональных дисциплин.

Может быть, и такие дисциплины, как «Основы теории литературы», «История отечественной литературы», «История зарубежной литературы» могут помочь, например, в освоении жанра рецензии на то или иное классическое произведение, будто оно написано современником. При сокращении часов на изучение истории литературы в два раза (по отношению к специалитету), мы вряд ли можем себе позволить роскошь проведения «традиционных» семинаров, когда студент зачитывает ответ на заранее известный ему единственный вопрос из интернет-приложения по мобильному телефону, с трудом разбирая случайно, впопыхах найденный текст по теме: мелко написано, да и читает его, как правило, впервые.

Также как «Риторика», являясь дисциплиной вариативной части коммуникативного модуля, дает основы технологии журналистского интервью, в рамках практических заданий. Кроме того, студенты пишут творческие работы на темы, которые на данный момент интересуют различные СМИ (например, «Сильное впечатление (в культурной, образовательной сфере)», «Телевидение в твоей жизни» и проч.). Лучшие работы первокурсников после презентации их перед сокурсниками и доработки с педагогом оперативно размещаются как в федеральных СМИ, так и в студенческой учебной газете «Проба пера», на сайте университета, на страничках кафедры журналистики в социальных сетях.

Авторский курс «Риторики», делового общения для журналистов, к сожалению, не предполагает изучения наследия античных риторов. За первый семестр первого курса надо сформировать не только имидж публичного человека, но и «вылепить» благожелательно настроенного, активного, по-хорошему пробивного студента из подчас агрессивного, наглого, критически настроенного или, наоборот, застенчивого, боящегося даже звука своего голоса школьника; если хотите, воспитать молодого журналиста, интеллигентного, сдержанного, умеющего слушать и уважительно относиться к собеседнику.

«При обучении важно нацеливать будущих журналистов на формирование коммуникативных (умение общаться, налаживать эффективную 
коммуникацию, владеть устным и письменным словом) и технологических качеств (умение находить факты, творчески их интерпретировать, владение современными информационными технологиями, способность выполнять разные роли и разные виды работ индивидуально и в команде)», - делает вывод выдающийся педагог и ученый, декан факультета журналистики Воронежского государственного университета, профессор В. В. Тулупов (Тулупов, 2006: 60). Эту нагрузку на первом этапе обучения берет на себя преподаватель дисциплины «Риторика».

Если каждый педагог профессиональных дисциплин, реализуя метод моделирования практической журналистской деятельности проработает три-четыре текста для студенческой газеты, и эти материалы будут рекомендованы к публикации, мы получим, как мне представляется, достаточно интересный результат. Пока же за первые два месяца нового учебного года редактор газеты получил по электронной почте от студентов две сотни сырых, как правило, беспомощных материалов... Конечно, здесь необходима деятельность всего коллектива преподавателей профессиональных дисциплин, чтобы помочь каждому студенту в самостоятельном выстраивании его профессиональной поведенческой модели как будущего журналиста.

При применении метода моделирования мы можем ориентироваться на идеальную модель выпускника бакалавриата по журналистике. «Это профессионально подготовленный к коммуникативной профессии и коммуникативному взаимодействию в универсальной и информационной среде индивид, способный принимать решения относительно формирования не только своей собственной, но и редакционной и аудиторной информационной картины дня» (Клюев, 2013: 29). На преподавательском уровне необходимо приложить все усилия для реализации этой модели в краткосрочной перспективе.

\section{СПИСОК ЛИТЕРАТУРЫ}

Бережная, М. А. (2014) Преподаватель журналистики: аспекты и оценка деятельности // Журналистика в 2013 году: регионы в российском медиапространстве. Сборник материалов Международной научнопрактической конференции / отв. ред. Е. Л. Вартанова, Я. Н. Засурский. М. : МедиаМир ; Факультет журналистики МГУ имени М.В. Ломоносова.

Блохин, И. Н. (2013) Цели журналистского образования в условиях перманентного социального кризиса // Средства массовой информации в современном мире. Петербургские чтения. УМО: Северо-Запад: Бюллетень № 10 / под ред. Л. Г. Фещенко. СПб.: С.-Петерб. гос. ун-т.

Бородай, А. Д. (2008) Восхождение к профессии. М.: Изд-во МосГУ.

Головин, Ю. А., Коханая, О. Е. (2015) Востребованные профессии в 
сфере масс-медиа: методика быстрого прогнозирования // Вестник Челябинского государственного университета. № 5 (360). Филология. Искусствоведение. Вып. 94. С. 365-371.

Грачев, С. В. (2013) Их учат журналистике, но не учат работать. Поэтому они много знают и мало умеют // Средства массовой информации в современном мире. Петербургские чтения. УМО: Северо-Запад: Бюллетень № 10 / под ред. Л. Г. Фещенко. СПб.: С.-Петерб. гос. ун-т.

Ильинский, И. М. (2006) Образование. Молодежь. Человек. М. : Из-во МосГУ.

Клюев, Ю.В. (2013) Журфак социуму: абитуриент - студент - выпускник // Средства массовой информации в современном мире. Петербургские чтения. УМО: Северо-Запад: Бюллетень № 10 / под ред. Л. Г. Фещенко. СПб. : С.-Петерб. гос. ун-т.

Кощиенко, И. В. (2014) Педагогический менеджмент как условие становления и развития современной системы образования //

Высшее образование для XXI века: XI Международная научная конференция. Москва, 27-29 ноября 2014 г. : Доклады и материалы. Секция 8. Педагогика и образование. Ч. 1. Педагогический менеджмент / отв. ред. Н. И. Федотова. М. : Изд-во Моск. гуманит. ун-та. 69 с. С. 6-9.

Летуновский, В. П. (2013) Метод моделирования в профессиональной подготовке журналистов // Средства массовой информации в современном мире. Петербургские чтения. УМО: Северо-Запад: Бюллетень № 10 / под ред. Л. Г. Фещенко. СПб. : С.-Петерб. гос. ун-т.

Сметанина, С. И. (2015) Инновационные методики в системе образования и эстетический опыт // Журналистика в 2014 году. СМИ как фактор общественного диалога. Сборник материалов международной научнопрактической конференции / отв. ред. Е.Л. Вартанова, Я.Н. Засурский. М. : МедиаМир, Факультет журналистики МГУ имени М. В. Ломоносова.

Смеюха, В. В. (2015) Особенности подготовки бакалавров по направлению «Реклама и связи с общественностью» // // Труды Ростовского государственного университета путей сообщения. №1 (30). С. 160-165.

Тулупов, В. В. (2006) Образовательные ценности и ориентации воронежских студентов. Воронеж.

Дата поступления: 15.11.2015 2.

Коханая Ольга Евгеньевна - доктор культурологии, профессор, заместитель заведующего кафедрой журналистики Московского гуманитарного университета. Адрес: 111395, Россия, г. Москва, ул. Юности, д. 5. Тел.: +7 (499) 374-60-91. Эл. адрес: kokhanaya@mail.ru 
Kokhanaya Olga Yevgenyevna, Doctor of Culturology,Professor and Deputy Chair, Department of Journalism, Moscow University for the Humanities. Postal address: 5 Yunosti St., 111395 Moscow, Russian Federation. Tel.: +7 (499) 37460-91.E-mail: kokhanaya@mail.ru 